\title{
Baur dam breach analysis using various manning's roughness values
}

\begin{abstract}
This paper describes the importance of flood mapping in terms of saving downstream agricultural area. Flood can cause high impact on the nearby crops productivity which further affects the country's economy. The Baur dam has a Culturable Command Area of 31453,6572 hectares. It's key focus is on describing the importance of Manning's roughness value in dam breach modelling and shows it's bad impact on downstream areas of dam. In this work hypothetical breach modelling of Baur dam is performed by using Hydrologic Engineer's Centre- River Analysis System (HEC-RAS). Details about study area, breach parameters, modelling procedure, and outflow flood values are also described in this paper. Flow hydrographs are plotted at different Manning's roughness value for the two populated downstream areas of dam and it has been observed from results that as roughness value increases flow decreases which justifies Manning's theory. As a Final result Inundation maps are plotted with the detail of inundated area values for different Manning's values so that the effect of roughness can be analysed numerically on study area. The Manning's roughness value of 0.030 causes $37.75 \mathrm{~km}^{2}$ inundated area in the downstream of dam. ${ }^{1}$
\end{abstract}

Volume 4 Issue 6 - 2020

\author{
Meenakshi Ramola, Jyothi Prasad, HJ Shiva \\ Prasad \\ Govind Ballabh Pant University of Agriculture and Technology, \\ India
}

Correspondence: Jyothi Prasad, Govind Ballabh Pant University of Agriculture and Technology, Pantnagar, Uttarakhand, India, Email profjyotiprasad@gmail.com

Received: September 15, 2020 | Published: December 29, 2020

Keywords: dam breach analysis, HEC-RAS, Inundation map, manning's theory, roughness parameter

\section{Introduction}

It is well known that dam is very beneficial to our society as it is valuable for power production, tourism, irrigation, water supply for households, and navigation etc. Baur dam is an irrigation dam with a Culturable Command Area of 31453,6572 hectares. It also has some negative side, such as if it fails due to any reason, causes high level of devastation in terms of life, economy, social and environmental etc. The main purpose of this dam is to provide irrigation water to the nearby areas, but if due to any reason the dam will break, it's affect not only the nearby areas, but the irrigation water supply will also affect badly. Recently in 2017, Central Water Commission circulated a report stating that about $1,07,487$ casualties took place in India due to flood and in last 64 years between 1953 to 2017, one-fifth of global death had occurred only due to flood (http://indiaenvironmentportal. org.in). This data shows the importance of present work as dam breach is one of the main cause of flood so, analysis of dam breach becomes important. Dam can fail because of various reasons such as: overtopping, piping, earthquake, high precipitation on upstream places, foundation failure, structure failure, landslide, etc. Earthen dam fails mainly because of overtopping and piping. In this work Baur dam breach analysis is considered which is an earthen dam and for analysis overtopping failure is considered at five different roughness values in the range of 0.030 to 0.040 . HEC-RAS is an example of semi-physical model and useful for flood planning and management. Methodology used for dam breach analysis in this work is two dimensional and it is shown with the help of Figure 1. The objective of this research is to provide an inundation map for the downstream areas of Baur dam and showing impact of manning's value in the flow parameters. According to Manning's theory, roughness coefficient is denoted by ' $n$ ' and this roughness value represent resistance to the flood flow in channels and in flood plains. Flow resistance can be defined as "the force to overcome or the work required to be done to counter the action of the rigid, flexible or moving boundary on the flow".

\section{Objective}

Baur dam breach analysis is performed with these objectives:

I. To plot an Inundation Map for the downstream areas of dam

II. Showing the effect of different Manning's values in the flood flow parameters

III. Risk analysis for the flooded area of Baur dam by showing the flow value of flooded water.

\section{Methodology of dam breach analysis}

\section{Study area description}

Baur dam is an Earthen dam and constructed on Baur and Kahrala rivers in Udham Singh Nagar district of Uttarakhand state with latitude $29008^{\prime} \mathrm{N}$ and longitude 79020 'E. Dam is having 17.98 meters height and 9500 meters length with the reservoir capacity of 103.37 Mcum. It's main purpose is irrigation for the areas of Udham Singh Nagar district of Uttarakhand and areas of Rampur district of Uttar Pradesh with the Culturable Command Area of 31453,6572 Hectares. The neighbouring cities of Baur dam are Nainital, Haldwani, Rudrapur, Bazpur and Gadarpur. The study area comes in the hilly and tarai region of Uttarakhand, for which five different Manning's roughness value are considered $0.030,0.033,0.035,0.038,0.040$ from the data provided by Chow VT.

\section{Data required}

In this work dam breach modelling is performed for finding the impact of different Manning's value on flow value of flood generated by dam breach. Modelling can be performed one dimensional, two dimensional or coupling of both, in this two dimensional modelling is considered. Selection of modelling totally depends on the usefulness and requirement of work. The data requirement changes according 
to modelling prospects. The detail of data required in this two dimensional work is as given below:

I. Digital Elevation Model (D.E.M.) of the Baur dam site (Bhuvan portal).

II. Salient features of dam and its hydraulic structures (Irrigation department).

III. Design flood hydrograph or probable maximum flood as upstream boundary condition.

IV. Manning's roughness coefficient value of site (V.T. Chow).

V. Normal depth at downstream of dam as downstream boundary condition.

\section{Methodology adopted}

The methodology adopted in this work is two dimensional using HEC-RAS model. HEC-RAS is developed by U. S. Army Corps of Engineers. This model can perform one dimensional, two dimensional and coupling of both 1D and 2D. The software is easily available to all researchers and can be downloaded easily from its site. HEC-RAS uses data provided by user and simulate it for different flow results and also provide animation video of flow in the downstream of dam. The video clearly gives the detail of flood generated because of dam failure and the user can analyse the flood devastation. The model simulate the resulting flood wave generated based on consequences of an upstream event and models downstream effect based on result of dam breach studies. Embankment dam failure analyses can be viewed as two-step process. First is the actual dam breach must be analysed, second the breach outflow must be routed to the downstream to determine the downstream resulting flood. Figure 1 shows the simulation process used in 2D HEC-RAS for dam breach modelling.

\section{Breach prediction methods}

The simplest approach of breach parameter prediction for modelling is by estimating the breach parameter using various empirical formulas as given by many researchers such as Froelich et al. ${ }^{2,3}$ Zhang and then compare their result with guidelines given by different agencies such as USACE, NWS, FERC. After complete analysis and calculation Von Thun \& Gillete breach parameters are considered and USACE 2007 guidelines are used in this work. According to them, breach width range comes out to be $8.9916 \mathrm{~m}$ to $89.916 \mathrm{~m}$, and the final breach parameters considered are: breach bottom width $=66 \mathrm{~m}$, side slope $=(0.5: 1.0)$, and breach development time is 0.36 hours. $^{4}$

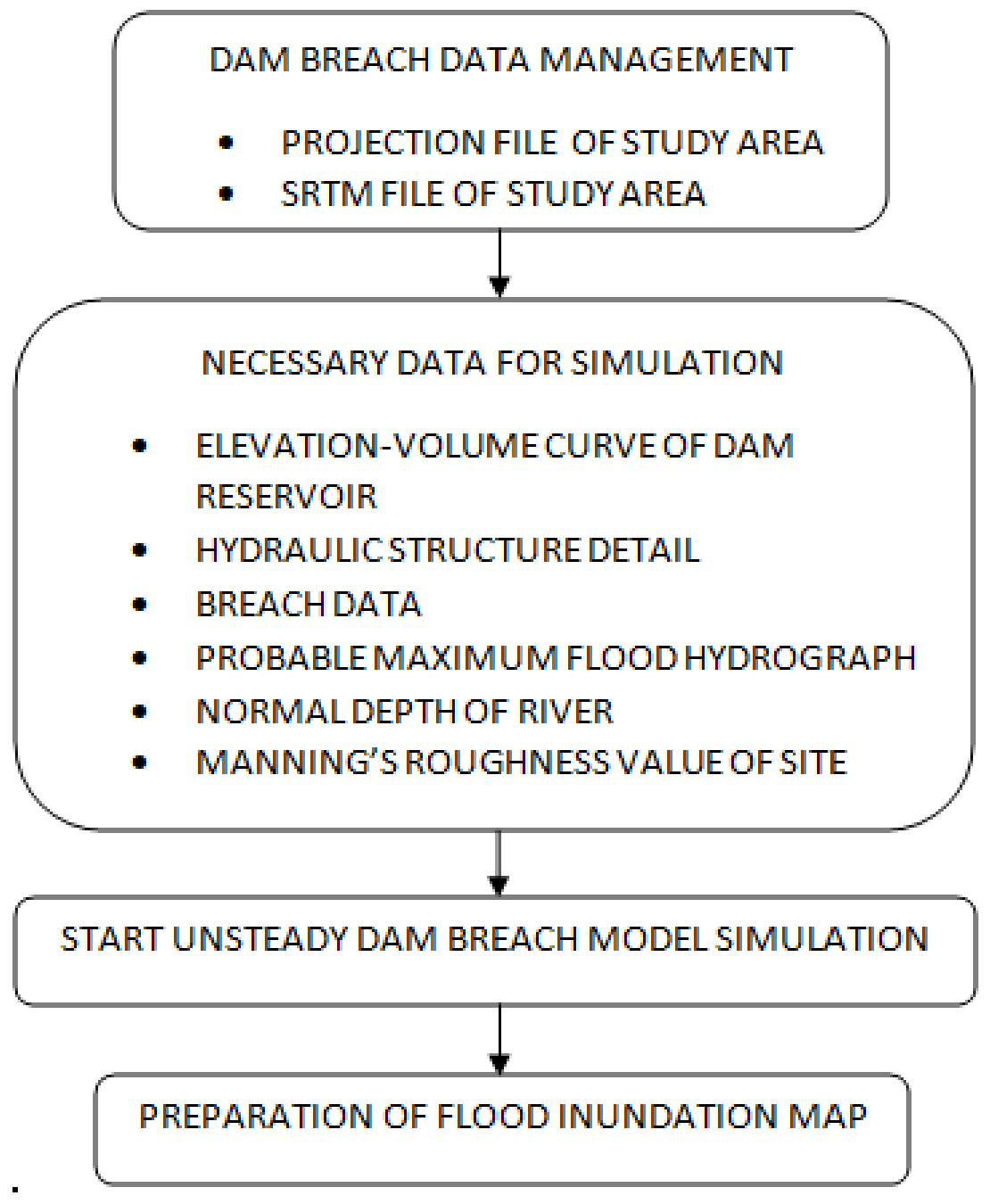

Figure I Flowchart used for 2D dam break modelling using HEC-RAS. 


\section{Dam breach analysis using HEC-RAS}

HEC-RAS is a computer program developed by U. S. Army Corps of Engineers for modelling natural river flows and other channels. It is easily available to public domain for research work. HEC-RAS 5.0.3 allows user to perform 1D, 2D and coupling of both within the software. Recently, in March, 2019 HEC-RAS Version 5.0.7 is released. Implicit Finite Volume algorithm solves the unsteady flow equation. ${ }^{5}$ For dam breach analysis accurate detail knowledge of dam and its hydraulic structure, prediction of breach parameters is required. In this work data is collected from Irrigation Department, Rudrapur, and Uttarakhand. For the development of inundation maps some key steps are processed: (a) Extraction of SRTM 30m DEM file (b) creating study area (c) applying structure detail and breach parameters (d) computation of hydrograph (e) producing flood inundation map. Flood inundation maps are helpful during relief operation at the time of flood so that loss of life can be minimized.

Table I Flow Values at Two Places for Five Different Manning's value

\section{Results}

The results are developed after hypothetical breach modelling of Baur dam by using 2D HEC-RAS at different Manning's value and then their flow hydrographs are compared. ${ }^{6}$ Variation of flow is observed at highly populated downstream areas of Baur dam named as Kelakhera and Bosena which are $10 \mathrm{~km}$ and $20 \mathrm{~km}$ respectively from dam location. ${ }^{7,8}$ Different Manning's roughness values are taken as: $\mathrm{n} 1=0.030, \mathrm{n} 2=0.033, \mathrm{n} 3=0.035, \mathrm{n} 4=0.038, \mathrm{n} 5=0.040$ and their inundated area detail is shown in Table 2 which proves the Manning's theory which states that as Manning's roughness value increases the flood flow value decreases also clear from Figure $2 \& 3$. Table 1 provides the detail of flow variation at different manning's values. Inundation map of Baur dam study area is shown in Figure 4 which is plotted with the help of QGIS and will be helpful in future for reducing flood hazards. Reservoir area of Baur dam is calculated as $11.23 \mathrm{Km}^{2}$ and the downstream inundated areas at different Manning's values are provided in the Table $2 .{ }^{9-11}$

\begin{tabular}{|c|c|c|c|c|c|}
\hline Place & $\begin{array}{l}\text { Flow for } n I= \\
(0.030) \text { Cumec }\end{array}$ & $\begin{array}{l}\text { Flow for } n 2= \\
(0.030) \text { Cumec }\end{array}$ & $\begin{array}{l}\text { Flow for } n 3= \\
(0.030) \text { Cumec }\end{array}$ & $\begin{array}{l}\text { Flow for } n 4= \\
(0.030) \text { Cumec }\end{array}$ & $\begin{array}{l}\text { Flow for } n 5= \\
(0.030) \text { Cumec }\end{array}$ \\
\hline Kelakhera & 562.74 & 359.41 & 319.89 & 304.45 & 261.57 \\
\hline Bosena & 313.18 & 312.99 & 309.87 & 305.66 & 301.31 \\
\hline
\end{tabular}

Table 2 Details of Inundated Area

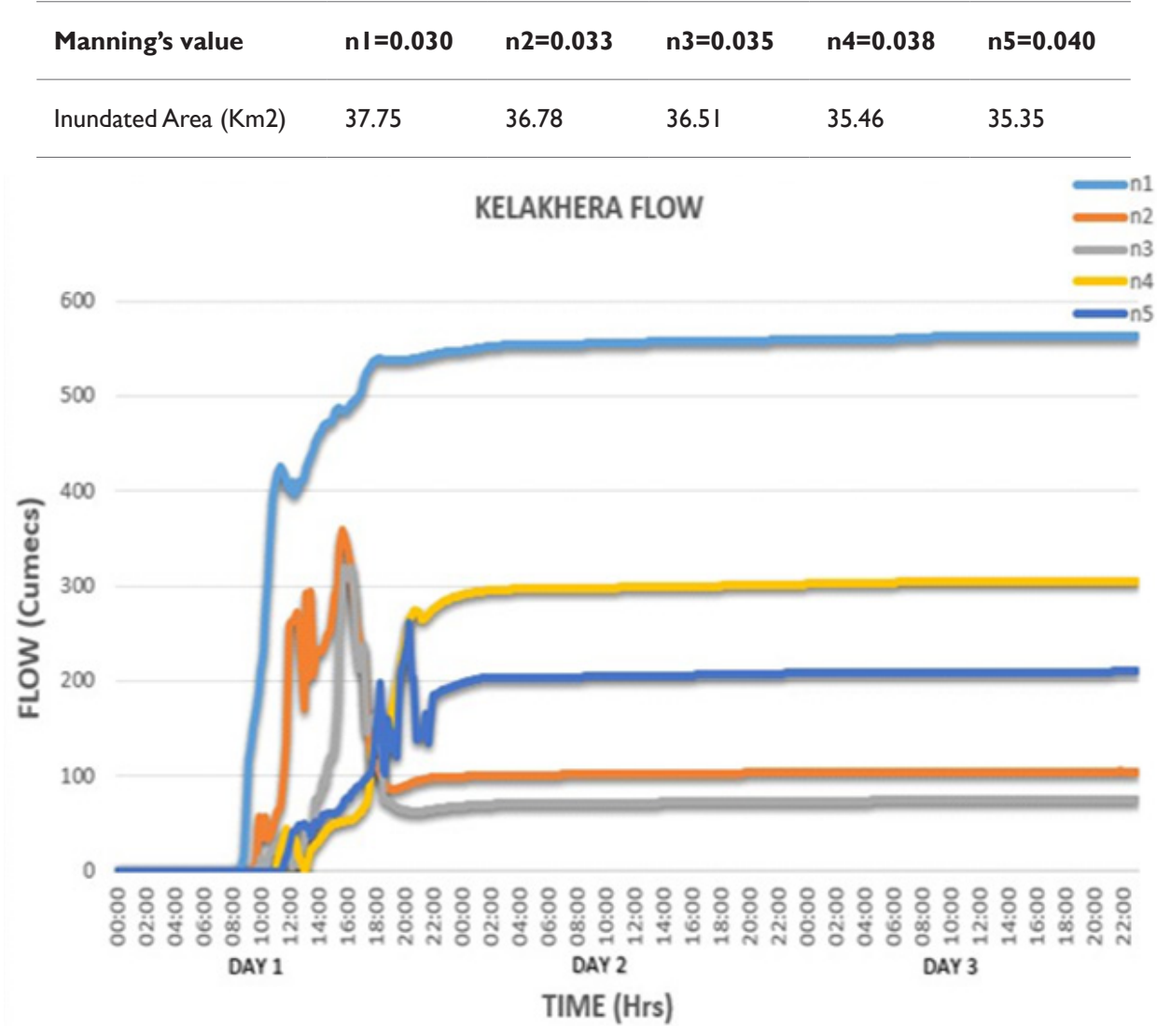

Figure 2 Flow vs Time for Kelakhera. 


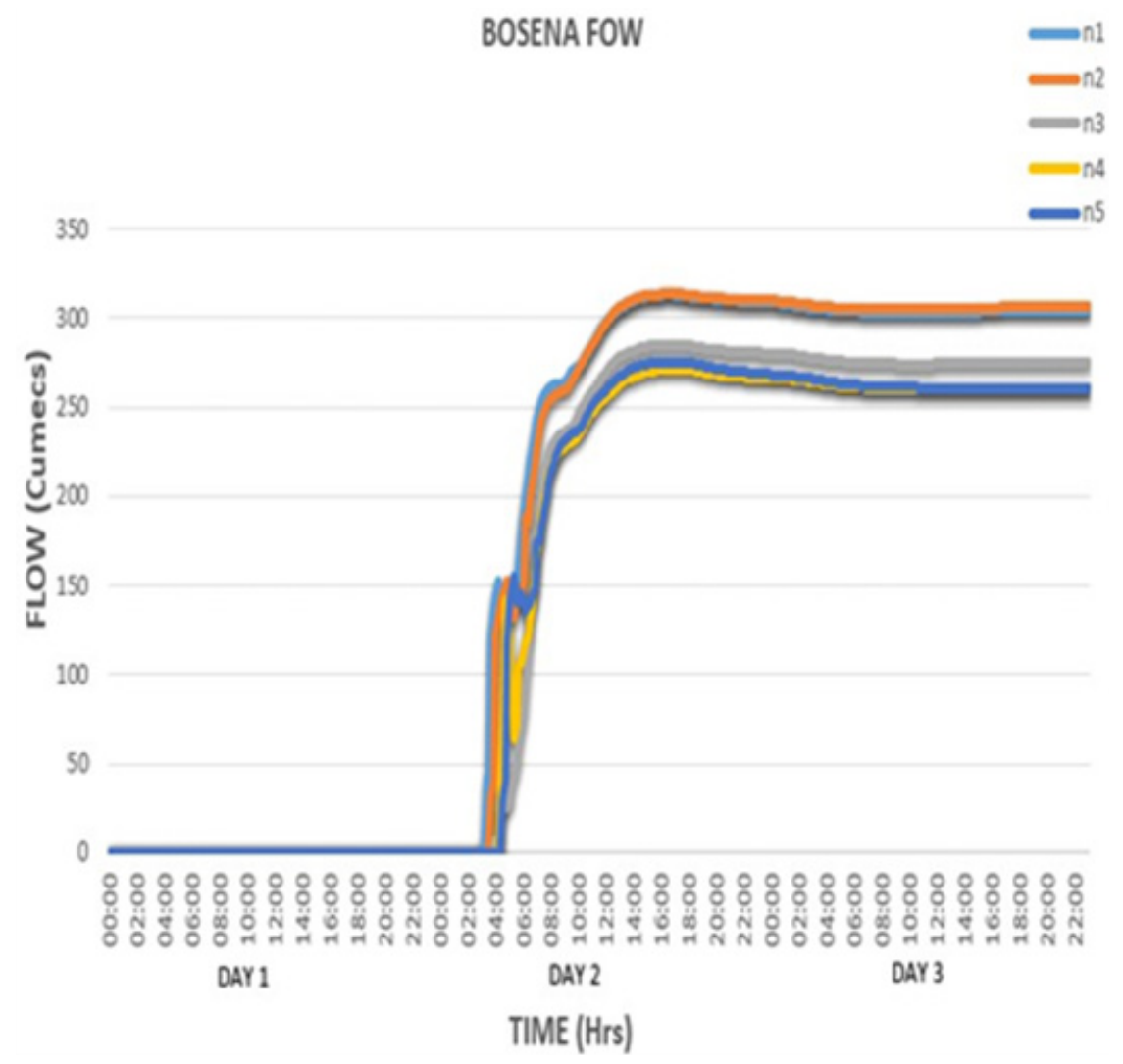

Figure 3 Flow vs Time for Bosena.

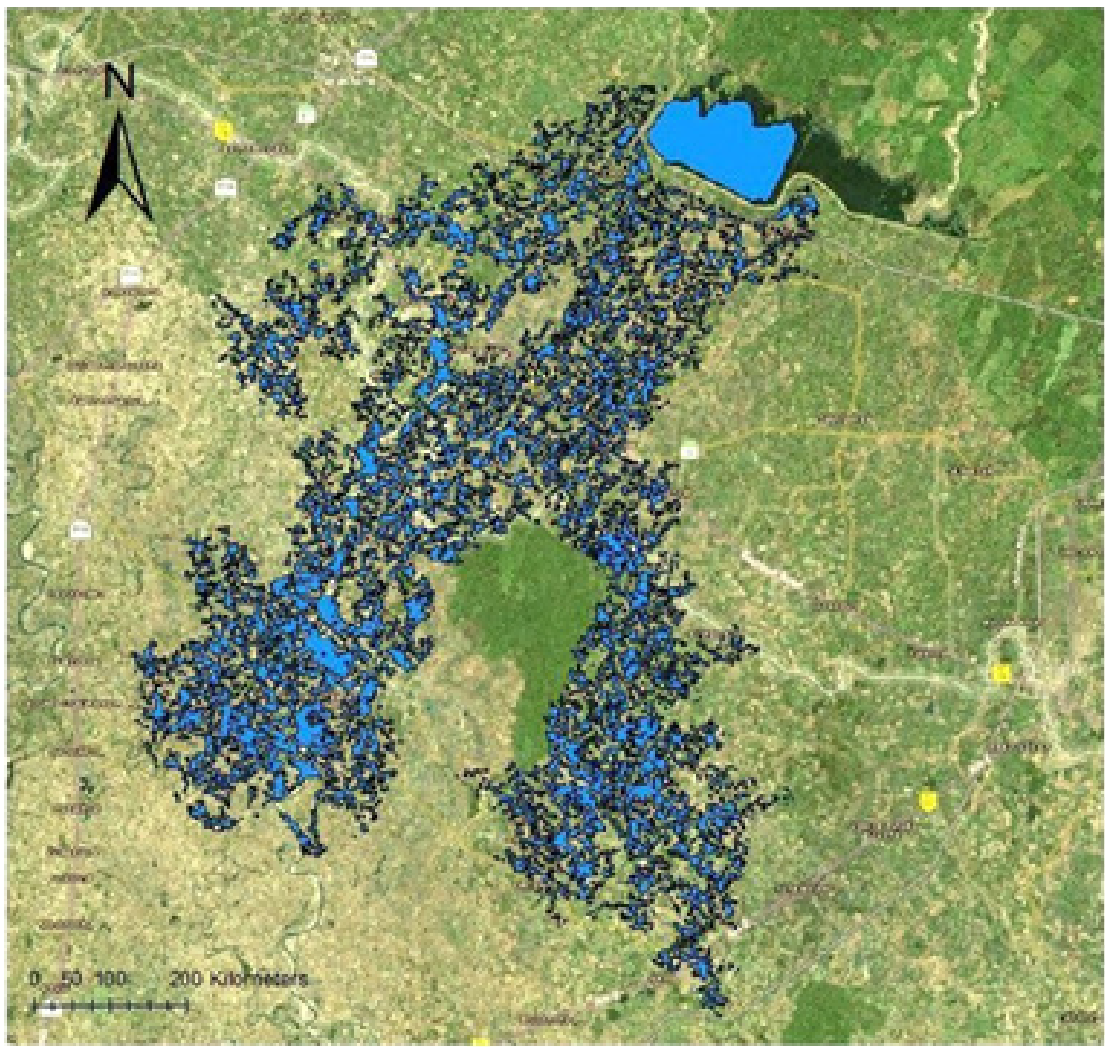

Figure 4 Inundation map for downstream areas of Baur dam. 


\section{Conclusion}

It has been concluded that as manning's value increases for site, the flow value decreases simultaneously at any considered location at the downstream of Baur dam and proved according to Manning's theory that roughness coefficient value is inverse of flow. Inundated area also includes the nearby irrigation area of dam site, and this detail will be helpful for the respected offices so that life, economic losses can be reduced. As roughness represent the resistance in channel, so when flow resistance increases as roughness coefficient increases, it produces retarding force on water and results lower flow rate value this theory is verified by the results shown in this paper. HEC-RAS 2D is a software that provides better understanding and analysis of flood to the downstream areas of dam after dam breach.

\section{Acknowledgments}

The authors are grateful for the support of Civil Engineering Department, College of Technology, and Govind Ballabh Pant University of Agriculture \& Technology, Pantnagar, and Uttarakhand.

\section{Conflicts of interest}

The author declares there is no conflict of interest.

\section{References}

1. Chow VT. Open-channel hydraulics. New York, McGraw-Hill, 1959. p. $101-123$.
2. Froelich DC. Peak Outflow from Breached Embankment Dam. ASCE Journal of Water Resources Planning and Management. 1995a;121(1):9097.

3. Froelich DC. Embankment Dam Breach Parameters and their Uncertainties. ASCE Journal of Hydraulics Engineering. 2008;134(12):1708-1721.

4. Macdonald, Jennifer Langridge-Monopolis. Breaching Characteristics of Dam Failure. ASCE Journal of Hydraulics Engineering. 1984;110(5):567586.

5. Thet Hnin Aye, Win Win Zin, U Tin Maung. Development of Flood Inundation Map for Bago River Basin. Interantional Journal of Innovative Research in Multidisciplinary Field. 2017;3(1):1-6.

6. TW Lau, NR Afshar. Effect of Roughness on Discharge. UNIMAS e-Journal of Civil Engineering. 2013;4(3).

7. Yi (Frank) Xiong. A Dam Break Analysis Using HECRAS. Journal of Water Resource and Protection. 2011;3:370-379.

8. M West. A guide to breach prediction. HR Wallingford. 2018.

9. Von Thun. Guidance on Breach Parameters. Internal Memorandum, U.S. Bureau of Reclamation, Denver, CO, 1990. p. 17.

10. Froelich DC. Embankment Dam Breach Parameters Revisited, first International Conference, Water Resource Engineering, Environmental and Water Resources Institute ASCE, Water Resources Engineering Proceedings. 1995b. p. 887-891.

11. India Environment Portal, Central Water Commission Report 2017, about large dams. 